\title{
3. Dawlatshāh's Lives of the Persian Poets
} (Tadhkiratu'sh-Shu'arā).

All those who are interested in the study of the Persian Language and Literature must have suffered grave inconvenience from the difficulty of obtaining access to many of the most indispensable books of reference, especially biographical and historical works to which the student constantly has occasion to refer. Many of the most important and most useful of these, such as the Tārikh-i-Guzida of Hamdu'llāh Mustawfī-i-Qazvīni, the Tadhkiratu'l-Awliyā of Farīdu'd-Dīn 'Ațtāar, etc., exist only in manuscript; while others, though they have been lithographed in the East, are hardly more accessible to European students, owing to the difficulty of obtaining copies, the inaccurate and illegible state of the text, and the complete absence of titles, paragraphs, and indices. To this latter class belongs the Tadhkiratu'sh-Shu'arā of Dawlatshāh, a work which, whatever its defects, is of capital importance to the student of Persian Literature. The only edition with which I am acquainted (Bombay, 1887) is a poor lithograph, presenting in many places a corrupt text, and entirely devoid of the indices and tables of contents which are so essential in a book of reference.

Having been for several years deeply impressed with the defective character of the apparatus wherewith the student of Persian is compelled to work, I have often contemplated the possibility of beginning, even though it be on a very modest scale, to remedy this state of things, by the gradual publication of a series of selected historical and biographical texts, based on the best available manuscripts, and provided with the necessary indices of the names of all persons, places, and books referred to in the text. Dawlatshāh's Tadhkira appeared to me, for reasons which it is not necessary to enumerate, the most suitable book with which to inaugurate this projected series, and the text of this, based on three Cambridge MSS. dated A.H. 984, 979, and 1104, and the lithographed edition, and collated in the 
more obscure and doubtful portions with old MSS. preserved in London, Paris, and Oxford, is now, together with the indices, completed and ready to be placed in the printer's hands. The question of how the cost of publication is to be defrayed has alone delayed thus long the appearance of the work, and I have now decided to risk a certain loss provided that sufficient support is promised to ensure the sale of 200 copies. For this support I now appeal to my fellow-students. Those who desire to subscribe are requested to signify their intention of so doing to Messrs. Luzac \& Co., 46, Great Russell Street (opposite the British Museum), London, W.C. The printing will begin as soon as the necessary support is guaranteed.

The price of the book to subscribers will be Twelve Shillings (15 francs, 12 marks) nett, not including postage, the Subscription to be payable by the Subseriber on delivery of the book, or on receipt of a notification that it is ready for delivery. After publication the price will be raised to Eighteen Shillings (22.50 francs, 18 marks).

Should the support necessary to defray at least two-thirds of the cost not be forthcoming, the publication of the text will not be proceeded with. If, on the other hand, the sale of the text should eventually prove sufficient to defray the entire cost of publication, the series will be continued with other Persian texts of a similar character, especially those historical and biographical works chiefly needed for reference.

Edward G. Browne,

Lecturer in Persian in the University of Cambridge. August, 1897. 